\title{
Real-time strategy to optimize the Airflow rate of Fuel Cell Hybrid Power Source under variable load cycle
}

\author{
Nicu Bizon ${ }^{1}$, Mihai Culcer ${ }^{2}$, Mihai Oproescu ${ }^{1}$, Gabriel Iana ${ }^{1}$, Ionescu Laurentiu ${ }^{1}$, Alin Mazare ${ }^{1}$, \\ Mariana Iliescu ${ }^{2}$ \\ ${ }^{1)}$ Faculty of Electronics, Communications and Computers, University of Pitesti, Pitesti, Romania \\ ${ }^{2}$ National Center for Hydrogen and Fuel Cell National Research and Development Institute for Cryogenics and \\ Isotopic Technologies, ICIT Ramnicu Valcea, Romania
}

\begin{abstract}
This paper proposes a Real-time optimization (RTO) strategy for Fuel Cell Hybrid Power Sources based on Global Extremum Seeking (GES) control of the air flow. The performance is shown in comparison with Static Feed-Forward RTO strategy.
\end{abstract}

Keywords: Real-time optimization (RTO) strategy; Fuel Cell Hybrid Power Sources (FCHPS); Global Extremum Seeking (GES); Static Feed-Forward (sFF)

\section{REAL-TIME OPTIMIZATION STRATEGIES}

Real-Time Optimization (RTO) strategies for Fuel Cell Hybrid Power Sources (FCHPS) usually use the Extremum Seeking (ES) algorithm [1], Model Predictive Control (MPC) [2], Equivalent Consumption Minimization Strategy (ECMS) [3], robust control [4], intelligent algorithms [5,6] and other techniques [7] to find the optimal point of operation.

The ECMS is one of most used RTO strategy, being based on Dynamic Programming (DP) [8] and Pontryagin's Minimum Principle (PMP) [9]. This is applied in optimization problems such energy management strategies with state inequality constraints [10] or multi-schemes technique [11]. Recently, the ES-RTO strategies are intensively studied based on Global ES (GES) algorithms proposed in the literature to find the global extreme on the multimodal optimization functions $[1,12]$.

Therefore, GES-RTO strategy is proposed here to optimize the operation of FCHPS. The Air_GES-RTO strategy proposed to control the air flow of FC stack is combined with Load-Following (LF) control [13] to obtain the following advantages: (1) it is not affected by load profile; (2) the performance is better than that of Static Feed-Forward (sFF) RTO strategy [14]; (3) the level of computation is low; (4) it can be implemented into real-time hardware solution.

\section{FUEl CELl Hybrid POWER SOURCE}

The effectiveness of Air_GES-RTO strategy will be

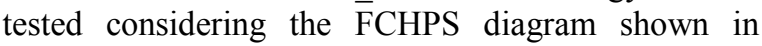
Figure 1, where the $6 \mathrm{~kW} / 45 \mathrm{~V}$ PEMFC, and the lithium-ion battery and ultracapacitors stack from ESS are those the SimPowerSystems library of the Matlab Simulink ${ }^{\circledR}[15]$. The control variables of the FC stack are considered the air and fuel flow rates (AirFr and FuelFr). The GES control will find the maximum value of $f$ function. The $\mathrm{I}_{\mathrm{GES}}$ value is used to adjust the AirFr value if the switch is on GES position. If the switch is set on sFF position, then both AirFr and FuelFr inputs are controlled by FC current as in the Air_sFF-RTO strategy (see Figure 1).

The default values are considered for the FC stack and $100 \mathrm{Ah} / 200 \mathrm{~V}$ batteries' stack. The initial StateOf-Charge (SOC) of battery was set at $80 \%$. The initial voltage, the capacity $(\mathrm{C})$, and the equivalent series and parallel resistors (ESR and EPR) of ultracapacitors stack was set to $100 \mathrm{~V}, 100 \mathrm{~F}, 0.1 \Omega$ and $10 \mathrm{k} \Omega$. The compressor is modeled as in [12], so the power of the air compressor, $P_{c m}$, is:

$$
P_{c m}=I_{c m} \cdot V_{c m}=\left(a_{2} \cdot \operatorname{AirFr}^{2}+a_{1} \cdot \operatorname{AirFr}+a_{0}\right) \cdot\left(b_{1} \cdot I_{F C}+b_{0}\right)
$$

where $\mathrm{a}_{0}=0.6, \mathrm{a}_{1}=0.04, \mathrm{a}_{2}=-0.00003231, \mathrm{~b}_{0}=0.9987$, and $b_{1}=46.02$. So, the FC net power is given by:

$$
p_{F C n e t} \cong p_{F C}-p_{c m}
$$

where $p_{F C}$ is the power generated by the FC stack and $p_{c m}$ is the power consumed by the air compressor. Consequently, the power flow balance on the DC bus is given by:

$$
C_{d c} u_{d c} d u_{d c} d t=\eta_{\text {boost }} p_{F C n e t}+p_{E S S}-p_{\text {Load }}
$$

where $p_{F C n e t}, p_{E S S}$, and $p_{\text {Load }}$ are the level of the FC net power, ESS power, and load demand, and $\eta_{\text {boost }}$ is the energy efficiency of the boost converter.

The LF control will operate the battery in ChargeSustained (CS) mode $\left(P_{E S S}=0\right)$ during a load cycle, so, the average (AV) value of the FC current requested by the load is:

$$
\begin{gathered}
0=\eta_{\text {boost }} P_{F C n e t}-P_{\text {Load }} \Rightarrow \\
I_{\text {refLF }}=I_{F C(A V)}=P_{\text {Load }} /\left(V_{F C} \cdot \eta_{\text {boost }(A V)}\right)
\end{gathered}
$$

where $\cdot \eta_{\text {boost }(A V)}$ is set to 0.95 .

Thus, the $I_{\text {refLF }}$ reference current is used as reference for control of the boost converter [16].

The optimization function is computed in the function block and will be detailed in next section. The GES algorithm used here has two control loops, being different to that proposed in $[17,18]$. It is able to dynamically track the global maximum of multimodal function $\mathrm{f}($ AirFf, FuelFr) [19-21]. 


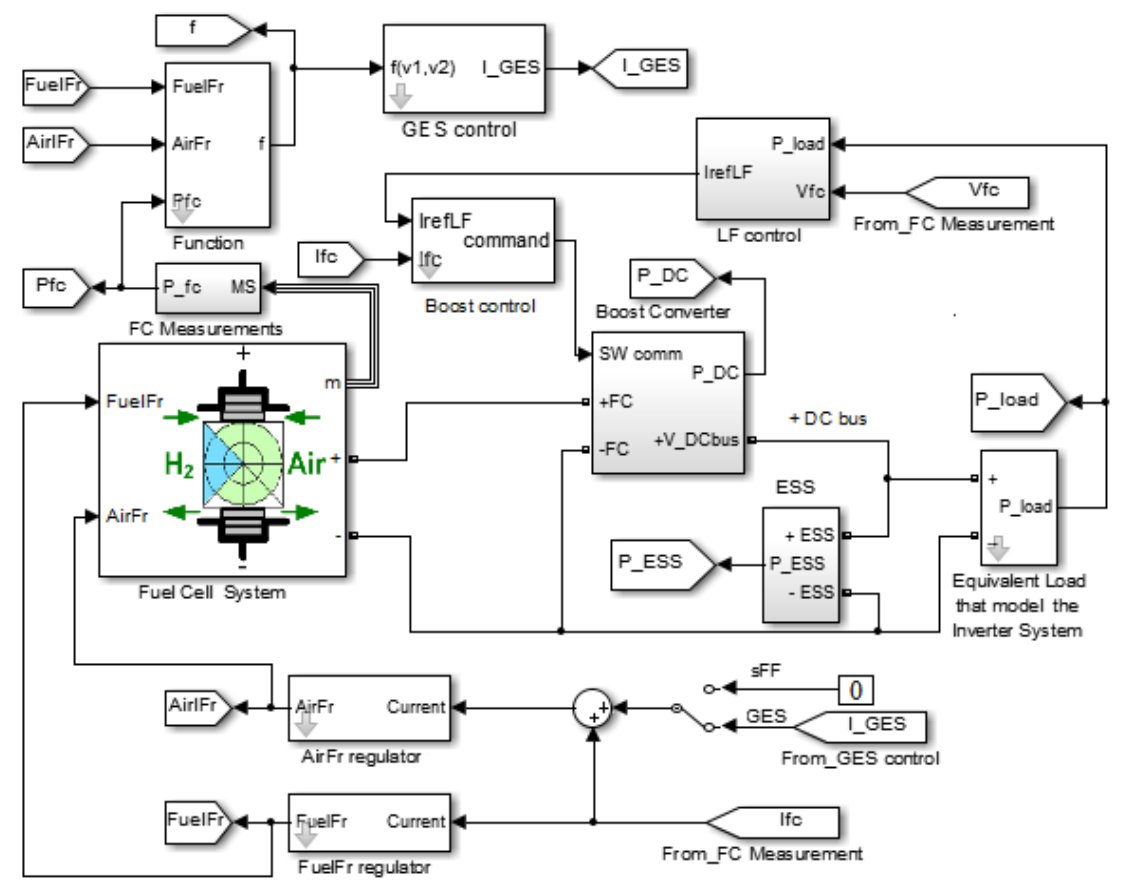

Figure 1. The FCHPS with selection of Air_GES-RTO strategy or Air_sFF-RTO strategy

\section{METHODOLOGY OF RESEARCH}

In this case, the optimization problem can be defined for FC system as [17]:

Maximize:

Subject to:

$$
P_{F C n e t}=f\left(x, \operatorname{AirFr}, I_{\text {Load }}\right)
$$

$$
\dot{x}=g\left(x, \operatorname{AirFr}, I_{\text {Load }}\right), x \in X
$$

where $x$ is the state vector, AirFr is the control input, $I_{\text {Load }}$ is the disturbance input, and $g$ is a smooth function that represents the dynamics of the FC system. The GES control will find the maximum value of $f$ function that will set the value of the $\mathrm{I}_{\mathrm{GES}}$ used to optimize the value of AirFr in the Air_GES-RTO strategy (the switch on GES position).

If the Air_sFF-RTO strategy is used (the switch is set on sFF position), then the correction to FC current is zero. Both AirFr and FuelFr inputs are controlled by FC current in the Air_sFF-RTO strategy. The design and operation of GES algorithm used here can be found in [20]. Note that the $P_{F C n e t}$ has many peaks on the plateau around the Maximum Efficiency Point (MEP) [22]. The MEP position varies with operating parameters (such as temperature, fueling, etc.) [14], but the GES algorithm can find accurately the MEP [23-26].

\section{RESULTS}

The results will be obtained considering the FCHPS diagram shown in Fig. 1, where the load that model the inverter system will be set as constant and variable load.

\section{A. Constant load}

Fig. 2 shows the behavior of the FCHPS under $30 \mathrm{~A}$ load, which means a load power of $6000 \mathrm{~W}$ (see the top plot), if the Air GES-RTO strategy is used. The FC net power supplied by FC stack to DC bus of 200 $\mathrm{V}$ is shown in the second plot. Note that $\mathrm{P}_{\mathrm{FCnet}}$ value is of $5416 \mathrm{~W}$ (see Table I). The ESS power flow is bidirectional, but the average value is about zero due to the LF control used to control the boost converter (see the third plot). The fueling flow rates are shown in next two plots and the optimal values are $\mathrm{AirFr}_{1}=345.1 \mathrm{lpm}$ and $\mathrm{FuelFr}_{1}=52.01 \mathrm{lpm}$. The performance indicators used in this study are the fuel consumption efficiency (Fuel eff $_{\text {), the }}$ FC system efficiency $\left(\eta_{\text {sys }}\right)$, and Total Fuel consumption $\left(\right.$ Fuel $\left._{\mathrm{T}}\right)$ during a load cycle (see last three plots in Fig. 1). The Fuel $l_{\text {eff }}$ is defined as net energy produced for consumed fuel.

The relations for the performance indicators are the following:

$$
\begin{aligned}
\text { Fuel }_{\text {eff }} & \cong P_{\text {FCnet }} / \text { FuelFr } \\
\eta_{\text {sys }} & =P_{F C n e t} / P_{F C} \\
\text { Fuel }_{T} & =\int F u e l F r(t) d t
\end{aligned}
$$

The values of performance indicators for $30 \mathrm{~A}$ load and Air_GES-RTO strategy are: Fuel $_{\text {effl }}=104.1$ $\mathrm{W} / \mathrm{lpm}, \quad \eta_{\mathrm{sys}}=86.16 \%$, and $\mathrm{Fuel}_{\mathrm{T} 1}=30.81$ 1. The values of performance indicators for different values of load are shown in Table I and Table II for Air_GES-RTO strategy and Air_sFF-RTO strategy, respectively. As can be observed, the values obtained for 30 A load are close for both strategies, so the the behavior of the FCHPS under Air_sFF-RTO strategy is almost the same as for Air_ $\bar{G} E S-R T O$ strategy shown in Fig. 2.

Searching of optimal values for $\mathrm{P}_{\mathrm{FCnet}}$ and Fuel $\mathrm{lff}_{\mathrm{ff}}$ is shown in Fig. 3 and 4 for FCHPS under Air_GESRTO strategy and $\mathrm{I}_{\text {load }}=30$ A. 


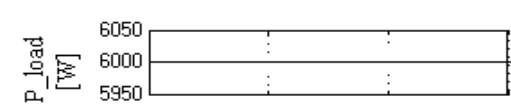

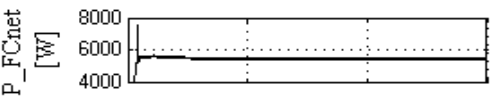
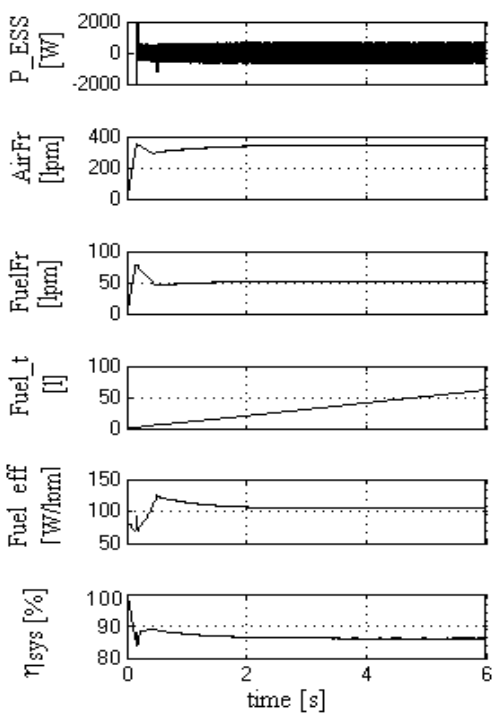

Figure 2. Searching of optimal point for FCHPS under Air_GESRTO strategy $\left(\mathrm{P}_{\text {load }}=6000 \mathrm{~W}\right)$

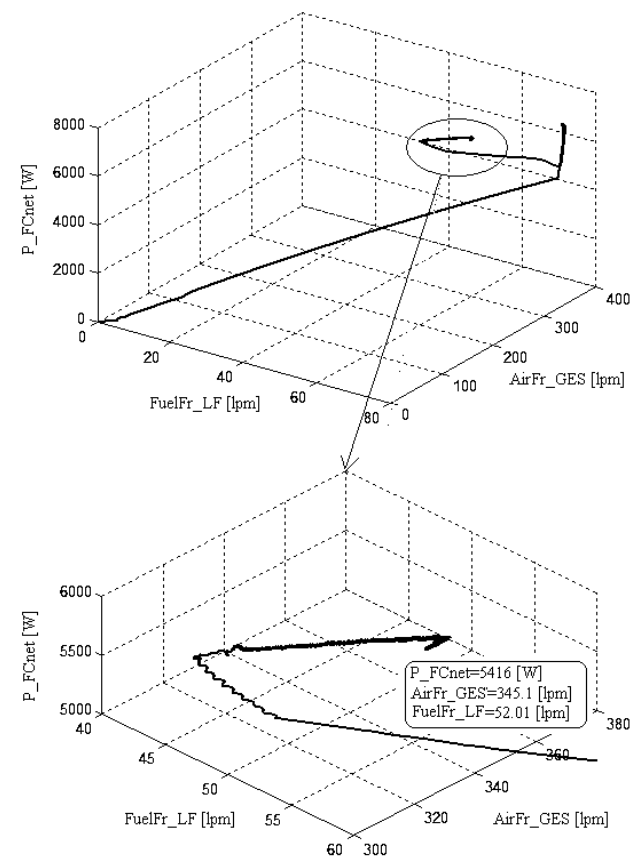

Figure 3. Searching of optimal $\mathrm{P}_{\mathrm{FCnet}}$ for FCHPS under Air_GESRTO strategy $\left(\mathrm{P}_{\text {load }}=6000 \mathrm{~W}\right)$

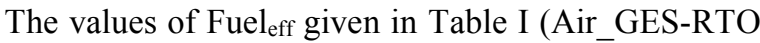
strategy) and Table II (Air_sFF-RTO strategy) are shown in Fig. 5. The superiority of Air_GES-RTO in comparison with Air sFF-RTO is not clearly shown because the other two performance indicators oscillate to be positive and negative from one strategy to the other strategy if different values of load are considered (see Table III). The differences between the values of performance indicators (mentioned in Table III) are shown in Fig. 6. Thus, the evaluation of the performance must be performed for a variable load in next section.

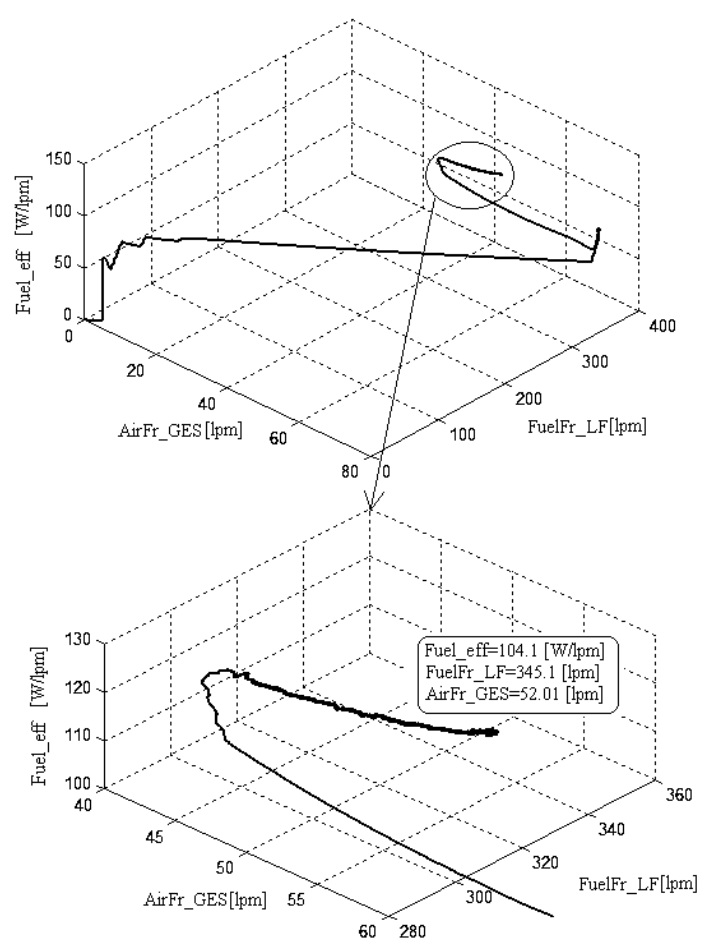

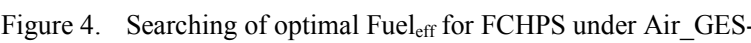
RTO strategy $\left(\mathrm{P}_{\text {load }}=6000 \mathrm{~W}\right)$

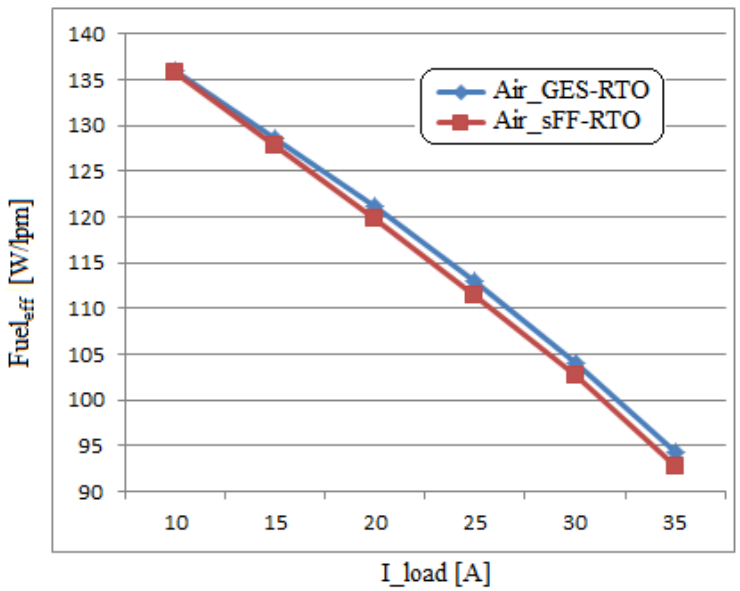

Figure 5. Fuel efficiency obtained using the Air_GES-RTO strategy and the Air_sFF-RTO strategy

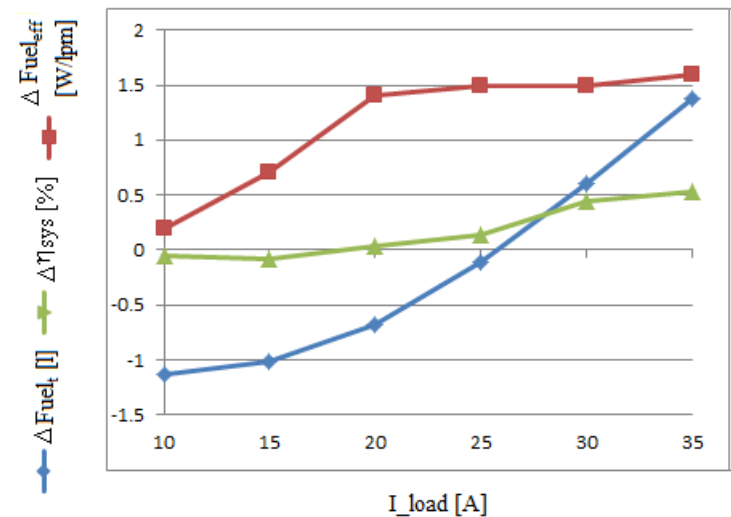

Figure 6. The differences between the performance indicators obtained with Air_GES-RTO strategy and Air_sFF-RTO strategy 


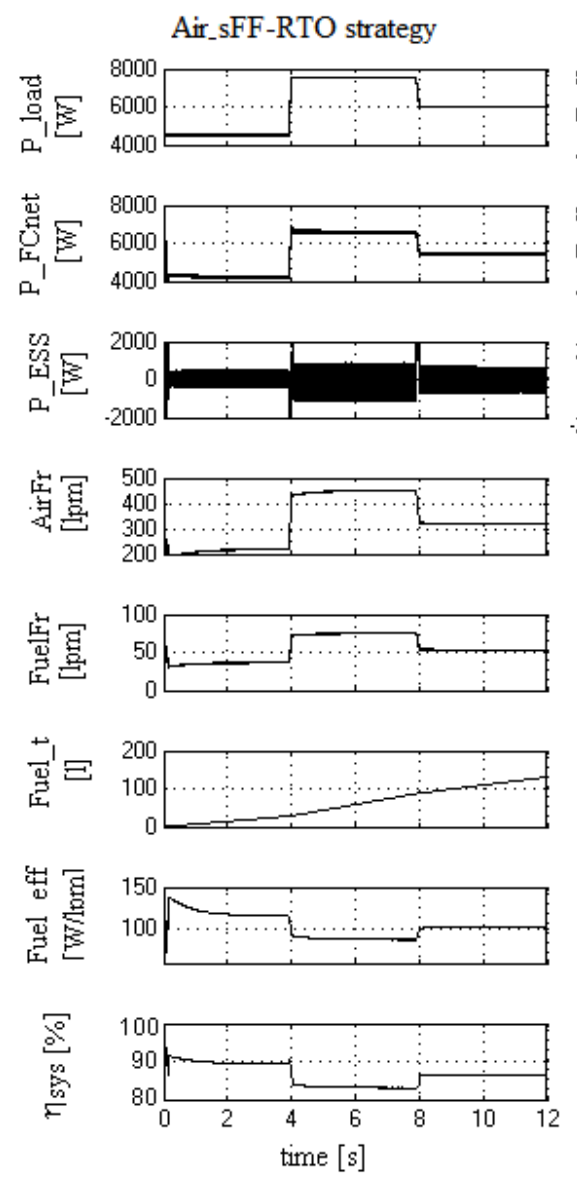

Air_GES-RTO strategy
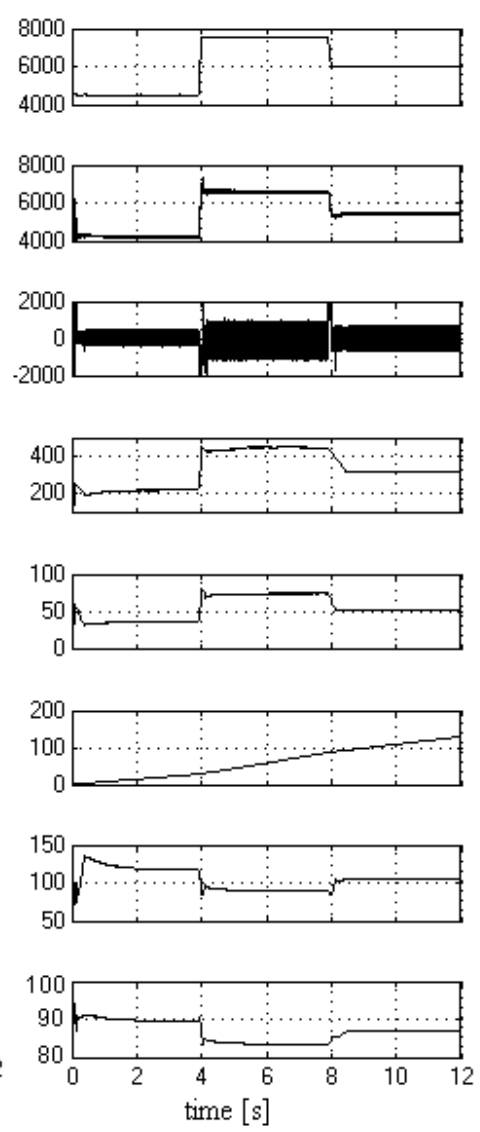

Figure 7. Searching of optimal point for FCHPS (under variable load cycle) if Air_GES-RTO strategy (right) or Air_sFF-RTO strategy (left) is used

TABLE I. THE AIR GES-RTO STRATEGY APPLIED TO FCHPS UNDER DIFFERENT I I TOAD

\begin{tabular}{|c|c|c|c|c|c|c|c|}
\hline $\mathbf{I}_{\text {load }}$ & $\mathbf{I}_{\mathrm{FC} 1}$ & FuelFr $_{1}$ & $\operatorname{AirFr}_{1}$ & $\mathbf{P}_{\mathrm{FCnet1}}$ & $\eta_{\mathrm{sys} 1}$ & Fuel $_{\text {eff1 }}$ & Fuel $_{\mathrm{T1}}$ \\
\hline$[A]$ & {$[A]$} & [lpm] & [lpm] & {$[W]$} & {$[\%]$} & {$[W / \mid p m]$} & [I] \\
\hline 10 & 35.89 & 14.05 & 105.3 & 1914 & 92.02 & 135.9 & 8.4 \\
\hline 15 & 57.79 & 22.08 & 159.4 & 2841 & 90.79 & 128.5 & 13.2 \\
\hline 20 & 83.1 & 31.12 & 190.3 & 3776 & 89.6 & 121.2 & 18.57 \\
\hline 25 & 109.4 & 40.98 & 248.4 & 4639 & 88.4 & 113 & 24.5 \\
\hline 30 & 137.2 & 52.01 & 345.1 & 5416 & 86.16 & 104.1 & 31.4 \\
\hline 35 & 177.2 & 66.51 & 400.9 & 6189 & 85.7 & 94.3 & 39.1 \\
\hline
\end{tabular}

TABLE II. THE AIR_SFF-RTO STRATEGY APPLIED TO FCHPS UNDER DIFFERENT I I LAD

\begin{tabular}{|c|c|c|c|c|c|c|c|}
\hline$\overline{I_{\text {load }}}$ & $\mathbf{I}_{\mathrm{FC} 2}$ & FuelFr $_{2}$ & $\operatorname{AirFr}_{2}$ & $\mathbf{P}_{\text {FCnet2 }}$ & $\eta_{\mathrm{sys} 2}$ & Fuel $_{\text {eff2 }}$ & Fuel $_{\mathrm{T}}$ \\
\hline$[A]$ & {$[A]$} & [lpm] & [lpm] & {$[W]$} & {$[\%]$} & [W/pm] & {$[I]$} \\
\hline 10 & 38.66 & 14.42 & 85.29 & 1938 & 93.16 & 135.7 & 8.45 \\
\hline 15 & 60.36 & 22.57 & 134.5 & 2875 & 91.81 & 127.8 & 13.28 \\
\hline 20 & 83.83 & 31.39 & 188.1 & 3777 & 90.28 & 119.8 & 18.54 \\
\hline 25 & 110.5 & 41.43 & 248.3 & 4636 & 88.51 & 111.5 & 24.37 \\
\hline 30 & 140.5 & 53.16 & 317.8 & 5444 & 85.56 & 102.6 & 30.96 \\
\hline 35 & 178.4 & 67.09 & 402.1 & 6190 & 84.33 & 92.7 & 38.57 \\
\hline
\end{tabular}

TABLE III. THE DIFFERENCES BETWEEN THE PERFORMANCE INDICATORS OBTAINED WITH AIR_GES-RTO STRATEGY AND AIR_SFFRTO STRATEGY AT DIFFERENT I IOAD

\begin{tabular}{|c|c|c|c|}
\hline $\mathbf{I}_{\text {load }}$ & $\Delta \eta_{\mathrm{sys}}=\eta_{\mathrm{sys} 1}-\eta_{\mathrm{sys} 2}$ & $\Delta$ Fuel $_{\text {eff }}=$ Fuel $_{\text {eff1 }}-$ Fuel $_{\text {eff2 }}$ & $\Delta$ Fuel $_{\mathrm{T}}=$ Fuel $_{\mathrm{T} 1}-$ Fuel $_{\mathrm{T} 2}$ \\
\hline$[A]$ & {$[\%]$} & [W/pm] & [I] \\
\hline 10 & -1.14 & 0.2 & -0.05 \\
\hline 15 & -1.02 & 0.7 & -0.08 \\
\hline 20 & -0.68 & 1.4 & 0.03 \\
\hline 25 & -0.11 & 1.5 & 0.13 \\
\hline 30 & 0.6 & 1.5 & 0.44 \\
\hline 35 & 1.37 & 1.6 & 0.53 \\
\hline
\end{tabular}




\section{B. Variable load}

The load cycle considered for both strategies is shown in top plot of Fig. 7 (Air_GES-RTO strategy on right side and Air_sFF-RTO strategy on left side).

The variable load is defined as pulsed profile, with 4 seconds for each level of $4500 \mathrm{~W}, 7500 \mathrm{~W}$, and 6000 $\mathrm{W}$. Note that average value of load demand is $6000 \mathrm{~W}$.
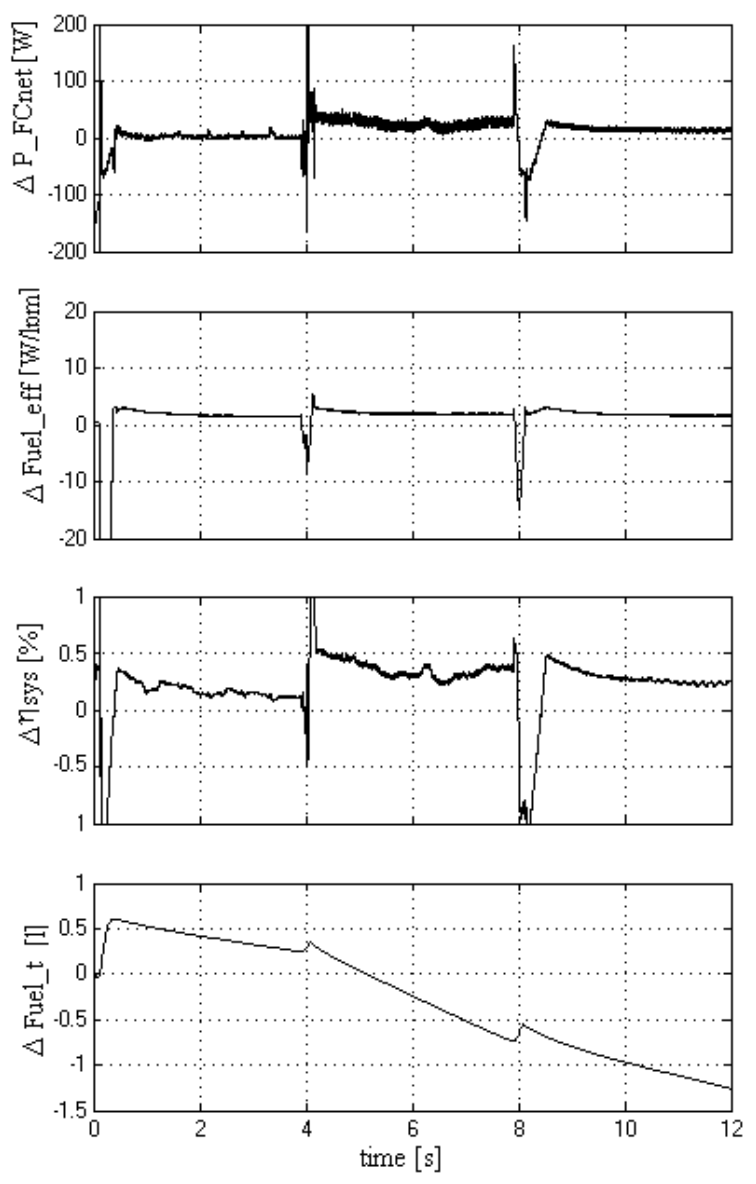

Figure 8. The performance of Air_GES-RTO strategy in comparison with Air_sFF-RTO strategy

Minor differences between the values of FC net power can be observed in the second plots of Fig. 7 .

The average value of ESS power flow due to the LF control used to control the boost converter is highlighted on the third plots.

The fueling flow rates are shown in next two plots and minor differences can be observed as well. The performance indicators are shown on the last three plots in Fig. 7.

The differences between the values of performance indicators shown in Fig. 7 are represented in Fig. 8. The superiority of Air_GES-RTO in comparison with Air_sFF-RTO is clearly shown now in all performance indicators.

\section{CONCLUSION}

The Air_GES-RTO strategy is proposed in this paper as new RTO strategy based on GES control of AirFr input.

The values obtained with Air_GES-RTO strategy for Fuel $_{\text {eff }}$ performance indicator are higher than those obtained with Air_sFF-RTO strategy with about 1.5 $\mathrm{W} / \mathrm{lpm}$ if the FC stack is operated around nominal condition. This performance is validated for $6 \mathrm{~kW}$ load cycle as well (see Figure 6 and 8).

For a variable load cycle of 12 seconds the fuel economy using the Air_GES-RTO strategy instead of Air_sFF-RTO strategy is about 1.41 , which it means about $1.1 \%$ reduction of fuel consumption per this 6 $\mathrm{kW}$ load cycle.

Also, for $6 \mathrm{~kW}$ constant and variable $6 \mathrm{~kW}$ load profiles, the FC system efficiency is higher with about $0.6 \%$ and $0.4 \%$ if Air_GES-RTO strategy is used instead of Air_sFF-RTO strategy.

\section{ACKNOWLEDGMENT}

The research that led to the results shown here has received funding from the following research projects of the Romanian National Authority for Scientific Research and Innovations, CNCS/CCCDI-UEFISCDI within PNCDI III: "Experimental validation of a propulsion system with hydrogen fuel cell for a light vehicle - Mobility with Hydrogen Demonstrator", 53PED, ID: PN-III P2-2.1-PED-2016-1223; and European Space Agency within STAR (Space Technology and Advanced Research): "Concept Development of an Energy Storage Unit Using High Temperature Superconducting Coil for Spacecraft Power Systems (SMESinSpace).

\section{REFERENCES}

[1] Ettihir K, Boulon L, Agbossou K. Optimization-based energy management strategy for a fuel cell/battery hybrid power system. Appl Energ 2016;163:142-153.

[2] Wang H, Huang Y, Khajepour A, Song Q. Model predictive control-based energy management strategy for a series hybrid electric tracked vehicle. Appl Energ 2016;182:105-114.

[3] Zhang W, Li J, Xu L, Ouyang M. Optimization for a fuel cell/ battery tram with equivalent consumption minimization strategy. Energ Convers Manage 2017;134:59-69.

[4] Matraji I, Laghrouche S, Jemei S, Wack M. Robust control of the PEM fuel cell air-feed system via sub-optimal second order sliding mode. Appl Energ 2013;104:945-957.

[5] Harrag A, Bahri H. Novel neural network IC-based variable step size fuel cell MPPT controller: Performance, efficiency and lifetime improvement. Int J Hydrogen Energ 2017; http://dx.doi.org/10.1016/j.ijhydene.2016.12.079.

[6] Mehne HH. Evaluation of Parallelism in Ant Colony Optimization Method for Numerical Solution of Optimal Control Problems. Journal of Electrical Engineering, Electronics, Control and Computer Science - JEEECCS 2015 1(2):15-20; http://jeeeccs.net/index.php/journal/article/view/17

[7] Castaings A, Lhomme W, Trigui R, Bouscayrol A. Comparison of energy management strategies of a battery/supercapacitors system for electric vehicle under realtime constraints. Appl Energ 2016;163:190-200.

[8] Peng J, He H, Xiong R. Rule based energy management strategy for a series-parallel plug-in hybrid electric bus 
optimized by dynamic programming. Appl Energ 2017;185(2):1633-1643

[9] Xu L, Ouyang M, Li J, Yang F, Jianfeng H. Application of Pontryagin's Minimal Principle to the energy management strategy of plugin fuel cell electric vehicles. Int J Hydrogen Energ 2013;38(24):10104-10115.

[10] Han J, Park Y, Dongsuk K. Optimal adaptation of equivalent factor of equivalent consumption minimization strategy for fuel cell hybrid electric vehicles under active state inequality constraints. J Power Sources 2014;267:491-502.

[11] Bassam AM, Phillips AB, Turnock SR, Wilson PA. Development of a multi-scheme energy management strategy for a hybrid fuel cell driven passenger ship. Int J Hydrogen Energ 2017;42(1):623-635.

[12] Ramos-Paja CA, Spagnuolo G, Petrone G, Emilio Mamarelis M. A perturbation strategy for fuel consumption minimization in polymer electrolyte membrane fuel cells: Analysis, Design and FPGA implementation. Appl Energ 2014;119:21-32.

[13] Bizon N. Load-following Mode Control of a Standalone Renewable/Fuel Cell Hybrid Power Source, Energ Convers Manage 2014;77:763-772.

[14] Pukrushpan JT, Stefanopoulou AG, Peng H. Control of fuel cell power systems. New York: Springer; 2004.

[15] SimPowerSystems TM Reference, Hydro-Québec and the MathWorks, Inc., Natick, MA; 2010.

[16] Mihaescu M. Applications of multiport converters. Journal of Electrical Engineering, Electronics, Control and Computer Science - JEEECCS 2016 2(1):13-18; available on http://jeeeccs.net/index.php/journal/article/view/25

[17] Ariyur KB, Krstic M. Real-time Optimization by Extremumseeking Control. Wiley-Interscience, Hoboken 2003.

[18] Bizon N. Tracking the maximum efficiency point for the FC system based on extremum seeking scheme to control the air flow. Appl Energ 2014;129:147-157.

[19] Oproescu M, Raducu M, Constantinescu LM, RamosHernanz JA, Lopez-Guede JM. Evaluation of the performance of new extremum seeking control algorithm to locate accurately the peaks on multimodal functions. Int conf on
Electronics, Computers and Artificial Intelligence - ECAI 2016; 10.1109/ECAI.2016.7861153.

[20] Bizon N, Thounthong P, Raducu M, Constantinescu LM. Designing and modelling of the asymptotic perturbed extremum seeking control scheme for tracking the global extreme. Int J Hydrogen Energ 2017; http://dx.doi.org/10.1016/j.ijhydene.2017.01.086.

[21] Bizon N, Oproescu M, Raducu M, Constantinescu LM. The extremum seeking control based on band pass filter for the dither signal processed in the control loop. IJTPE 2013;5(3):133-141; available on http://www.iotpe.com/IJTPE/IJTPE-2013/IJTPE-Issue16Vol5-No3-Sep2013/20-IJTPE-Issue16-Vol5-No3-Sep2013pp133-141.pdf).

[22] Meyer Q, Himeur A, Ashton S, Curnick O, Clague R, et al. System-level electro-thermal optimisation of aircooled opencathode polymer electrolyte fuel cells: Air blower parasitic load and schemes for dynamic operation. Int $\mathrm{J}$ Hydrogen Energ 2015;40:16760 - 66.

[23] Hoarca IC, Raducu M. On the micro-inverter performance based on three MPPT controllers. Journal of Electrical Engineering, Electronics, Control and Computer Science JEEECCS $2015 \quad 1(1): 7-14 ; \quad$ available on http://jeeeccs.net/index.php/journal/article/view/9

[24] Bizon N. Global Maximum Power Point Tracking (GMPPT) of Photovoltaic array using the Extremum Seeking Control (ESC): A review and a new GMPPT ESC scheme, Renew Sustain Energy Rev 2016;57:524-539.

[25] Molaei S, Jalilzadeh S, Mokhtarifard M. A new controlling method for maximum power point tracking in photovoltaic systems. IJTPE 2015;7(1):1-7; available on http://www.iotpe.com/IJTPE/IJTPE-2015/IJTPE-Issue22Vol7-No1-Mar2015/1-IJTPE-Issue22-Vol7-No1-Mar2015pp1-7.pdf.

[26] Bizon N. Global Extremum Seeking Control of the Power Generated by a Photovoltaic Array under Partially Shaded Conditions, Energ Convers Manage 2016;109:71-85 